\title{
QUANTITATIVE CORONARY PLAQUE CHARACTERIZATION WITH MULTIDETECTOR CT ANGIOGRAPHY
}

\author{
Ahmed Mostafa Mohamed, Amir Louis Loka, Ali Hagag Ali, and \\ Shaimaa Salah Mohamed*
}

\begin{abstract}
:
Department of Radiology,

Faculty of medicine, Ain shams University.

Corresponding :

Shaimaa Salah Mohamed Abdelrazik

Mobile: 1226009141

E mail:

Sheem1288@gmail.com

Received: 20/6/2019

Accepted: 24/7/2019

Background: Coronary artery disease (CAD) is a major cause of morbidity and mortality. Coronary atherosclerosis is a progressive disease with sudden destabilizing changes leading to plaque thrombosis and reorganization.

Aim of work: Quantitatively characterize coronary atherosclerotic plaque composition in patients with CAD referred to Ain shams radiology department (El Demerdash Hospital) by using CT coronary angiography and compare prevalence of different plaque types.

Patients and Methods: Seventy-eight patients of CAD symptoms (49 male, 29 female; mean age, 54.8 years) underwent CT coronary angiography (CTCA). Each patient underwent a non-contrast scan to determine the calcium score, then a contrast enhanced ECG gated scan. Coronary plaques were analysed as regard number, type, severity and plaque volumes by using semiautomated software.

Results: 14 patients had normal CTCA, 37 patient had significant obstructive lesions, and 4 of them had a totally occluded coronary vessel. A total of 232 coronary vessel plaques were found. The number of patients with multi-vessel disease was significantly higher in diabetic patients verses non diabetics. Noncalcified plaques were more prevalent (than calcified plaques), in patients $<55$ years, where $56.4 \%$ of their plaques were noncalcified, however in patients $>55$ years only $39.3 \%$ of their plaques were noncalcified.

Conclusion: Multi-slice CTCA is the non-invasive alternative to intravascular ultrasonography (IVUS) for plaque quantification, it is a reliable technique to detect $C A D$ and estimate the degree of obstruction, number of affected vessels and the pattern of their affection. Using automated software provide the major advantage of higher reproducibility.

Keywords: Coronary artery calcium (CAC), Coronary artery disease (CAD), Calcified coronary plaques (CCP), CT Coronary angiography (CTCA), Intravascular ultrasonography (IVUS), Left Circumflex coronary artery (LCX), Left anterior descending coronary artery (LAD), Left main (LM), Right coronary artery (RCA), Noncalcified plaques (NCP).
\end{abstract}

\section{INTRODUCTION:}

Coronary artery disease remains a major cause of morbidity and mortality. Presence of atherosclerotic plaques in a coronary artery is responsible for lumen stenosis ${ }^{(1)}$.

Different imaging modalities are used to understand intracoronary plaques, such IVUS, IVUS with virtual histology (IVUS- 
VH), elastography, intravascular Optical coherence tomography (OCT). Collectively, these technologies have the disadvantage of being inherently invasive ${ }^{(2)}$.

There is a growing evidence to show that CTCA has good correlation with IVUS in the quantitative plaque analysis ${ }^{(3)}$.

CTCA permits the non-invasive evaluation of the coronary atherosclerosis. CTCA provides information regarding the coronary tree, luminal narrowing, types of plaques, noncoronary cardiac and extracardiac thoracic abnormalities, including myocardial, pericardial, valvular and vascular lesions ${ }^{(4)}$.

The assessment of coronary artery plaque composition and size are potentially more important than traditional detection of luminal stenosis in predicting devastating acute coronary events ${ }^{(5)}$.

Non-calcified or low-attenuating plaques were more often seen in patients associated with acute coronary syndrome or development of major adverse cardiac events when compared to those with stable angina pectoris. Therefore, assessment of non-calcified plaque in terms of total plaque volume has significant clinical value ${ }^{(3)}$.

Coronary calcification alone can underestimate total plaque burden. Noncalcified plaques, play a crucial role in the development of acute coronary syndrome (ACS) and sudden thrombotic occlusion $^{(6)}$.

Prior Percutaneous coronary interventions, CTCA can be helpful in detecting low attenuating plaques (lipid rich ones) which may cause periprocedural distal emboli (following balloon dilatation), thus may help in shifting Percutaneous coronary intervention strategy toward the use of direct stenting, stronger antithrombotic therapy or preprocedural statin therapy for plaque stabilization $^{(7)}$.

CTCA provides information regarding the coronary tree in order to develop personalized medical care to enable therapeutic interventions ${ }^{(5)}$.

By the help of semiautomated plaque analysis software, we can obtain accurate and reproducible quantitative measurements, in order to facilitate the serial assessment of atherosclerotic burden by $\mathrm{CTCA}^{(8)}$.

\section{AIM OF WORK:}

Quantitatively characterize coronary atherosclerotic plaque composition in patients with CAD referred to Ain shams radiology department (El Demerdash Hospital) by using CT coronary angiography and compare prevalence of different plaque types.

\section{PATIENTS AND METHODS:}

A total number of 78 patients with symptoms of coronary artery disease were scheduled for elective CTCA between September 2017 and January 2019. Patients were referred to CTCA to investigate recent onset of dyspnea on exertion, fatigue on mild effort or ischemic chest pain (retrosternal heaviness or squeezing sensation that may radiate to the left arm, neck, back or lower jaw).

\section{The exclusion Criteria:}

- patients with known severe contrast allergy

- renal dysfunction with serum creatinine $>2 \mathrm{mg} / \mathrm{dL}$

- previous bypass operation

- unstable clinical condition (severe heart failure, severe pulmonary disease)

- contraindications to $\beta$-blockers (bronchial asthma)

- inability to perform a 10 -second breath hold

- patients with uncontrolled arrhythmia

- pregnant females 
All patients were subjected to the following:

- Obtaining an informed consent

- Full history: Including history of systemic hypertension, DM and smoking

- Reassurance of the patient was done and all steps of the study were explained in detail to each patient.

- Intravenous access was established in a cubital vein.

- One-hour pre-examination, patients received oral beta-blocker to reduce the heart rate. Sublingual nitroglycerin was administered prior to the scan (0.4-0.8 mg dose)

Scanning parameters and image acquisition:

Patients underwent CTCA using MDCT scanners (80 slice, Aquilion Lighting, Toshiba medical systems and 128 slice, OPTIMA, GE health care), at Ain Shams university hospitals (El Demerdash hospital), Radiology department.

(1) A noncontrast scan was performed to determine the calcium score

(2) The contrast-enhanced scan was obtained within one single breath-hold, using either a retrospective electrocardiogram (ECG)-gated protocol or prospectively with ECG-triggering depending on patient's heart rate. A bolus of 370 $\mathrm{mg} / \mathrm{mL}$ iodinated contrast material was injected intravenously followed by a $30 \mathrm{~mL}$ saline flush. Reconstructions were performed at $40 \%, 75 \%$, and $80 \%$ phases of the R-R interval period.

\section{Image analysis:}

CT data were transferred to workstations (AW volumeshare 7, GE medical systems and 3D synapse, Fujifilm).

Total calcium scores for the patients were calculated and expressed by Agatston score. The Agatston score calculates the total amount of calcium on the basis of the number, areas and peak Hounsfield units (HU) of the detected calcified lesions.

Coronary trees were analysed using 17 segment model. Only the major epicardial vessels were considered for analysis. Manual tracing of the coronary segments is done to detect plaques, followed by semi-automated quantification of different types of plaques.

Plaques were classified into; (i) noncalcified plaque: with no detectable calcium; (ii) mixed plaque: calcified tissue occupying $50 \%$ of a single cross-section within it; (iii) calcified plaque: calcified tissue occupying $\geq 50 \%$ of a single cross-section within it.

Software CT image colour coding was helpful, depending on Hounsfield units (HU), to better differentiate the plaque characteristics. Hounsfield units -50 to-1 coded red, indicating fatty tissue, HU 0 to 29 were coded orange, indicating a super soft spot; HU 30 to 129 were coded green and dark green, indicating a soft plaque; Hounsfield units 500 to 800 were coded yellow, indicating calcification; and HU 130 to 499 were coded as blue, indicating a contrast-filled lumen (Diagram. 1).

The colour coding described above was able to produce the plaque images; calcified plaque (coded yellow), non-calcified plaque (coded green and dark green)

Volume of different types of plaques was automatically calculated, by subtracting the lumen volume from the outer wall volume, and expressed in $\mathrm{mm}^{3}$ (Diagram. 2).

Atherosclerotic lesions were quantified for stenosis by visual estimation. The severity of luminal-diameter stenosis was divided into nonobstructive plaques ( $\leq 50 \%$ luminal stenosis) and obstructive plaques ( $>50 \%$ luminal stenosis). 


\section{Ahmed Mostafa Mohamed, et al.,}

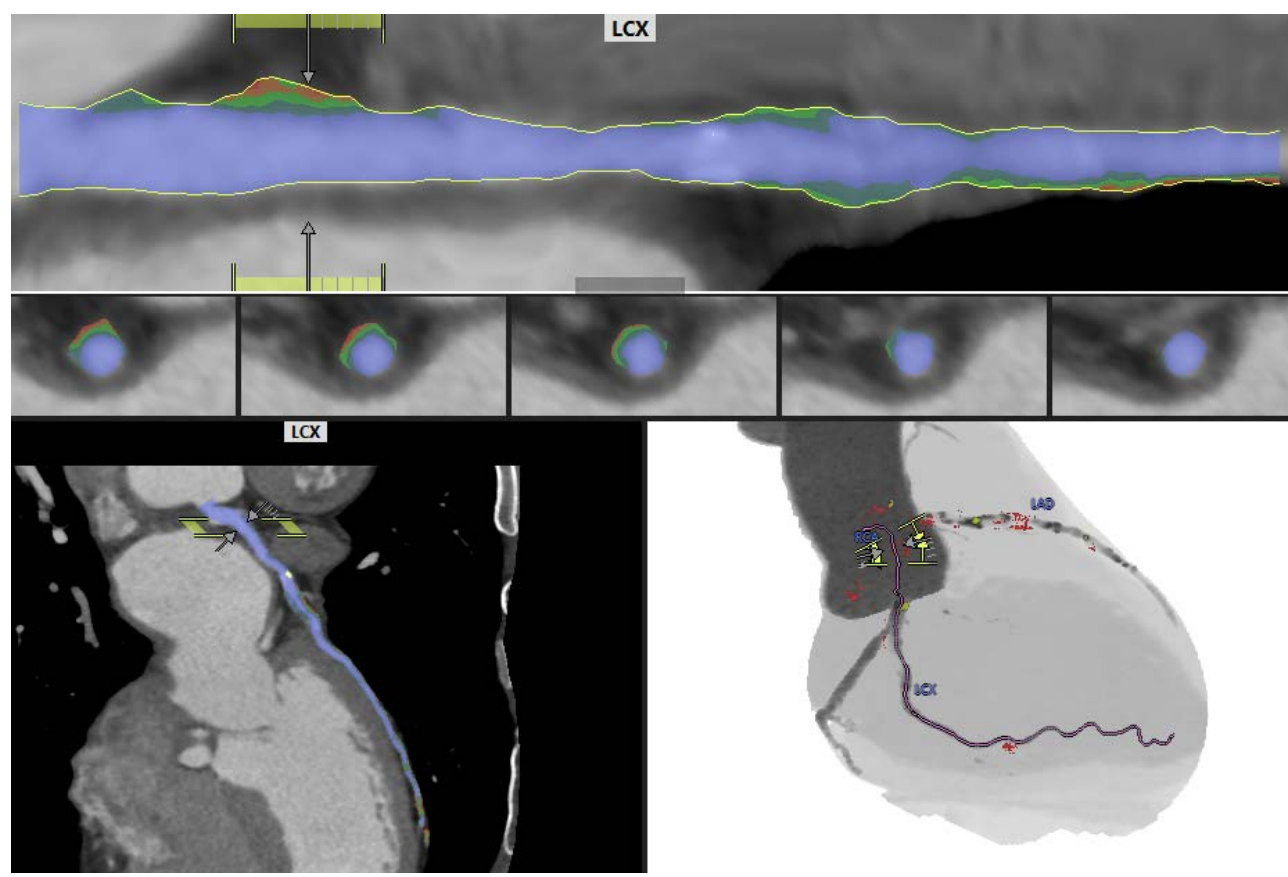

Diag. (1): Segmentation of LCX a with vascular model and coronary cross sections. Plaque volume is the sum of all plaque component volumes.
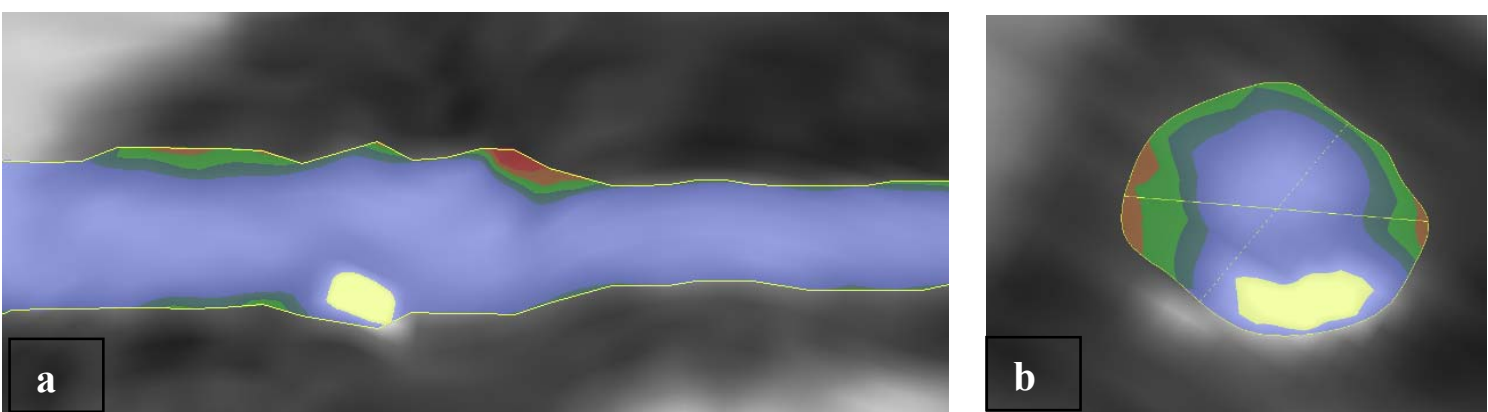

Diag. (2): Automated plaque detection. Vessel MPR(a), cross section (b), with calcified (posterior wall) and soft plaques (anterior, lateral wall).

\section{RESULTS}

\section{Population Demographics}

The study population consisted of 78 patient, presented with symptoms of coronary artery disease. The sample was
$37.2 \%$ female, $62.8 \%$ male. $51.3 \%$ of patients were hypertensive, $46.2 \%$ were diabetic and $39.7 \%$ were smokers. Population demographics and CAD risk factors by the presence or absence are shown in Table 1.

Table (1): Population demographics and CAD risk factors by the presence or absence

\begin{tabular}{|l|l|c|}
\hline \multirow{2}{*}{ Age } & Mean \pm SD & No. $=78$ \\
\cline { 2 - 3 } & Range & $54.86 \pm 7.82$ \\
\hline \multirow{2}{*}{ Gender } & Female & $37-75$ \\
\cline { 2 - 3 } & Male & $29(37.2 \%)$ \\
\hline Smoking & $49(62.8 \%)$ \\
\hline HTN & $31(39.7 \%)$ \\
\hline DM & $40(51.3 \%)$ \\
\hline \multicolumn{2}{|c}{} & $36(46.2 \%)$ \\
\hline
\end{tabular}




\section{Prevalence of Coronary Plaque}

Among 78 patients, 14 (17.9\%) had normal CTCA, 21(26.9\%) had three vessel disease and $2(2.6 \%)$ had three vessel with LM affection. 37 patient had significant obstructive lesions, and 4 of them had a totally occluded coronary vessel.

Table (2): The prevalence of coronary plaque by age.

\begin{tabular}{|c|c|c|c|c|c|c|}
\hline & Age $<55$ & Age $\geq 55$ & \multirow[t]{2}{*}{ Test value } & \multirow[t]{2}{*}{ P-value } & \multirow[t]{2}{*}{ Sig. } \\
\hline & & No. $=35$ & No. $=43$ & & & \\
\hline \multirow[t]{2}{*}{ plaque } & Absent & $10(28.6 \%)$ & $2(4.7 \%)$ & \multirow[t]{2}{*}{8.481} & \multirow[t]{2}{*}{0.004} & \multirow[t]{2}{*}{$\mathrm{HS}$} \\
\hline & Present & $25(71.4 \%)$ & $41(95.3 \%)$ & & & \\
\hline \multirow{5}{*}{$\begin{array}{l}\text { No. of } \\
\text { vessels } \\
\text { affected }\end{array}$} & 0 & $10(28.6 \%)$ & $4(9.3 \%)$ & \multirow[t]{5}{*}{9.740} & \multirow[t]{5}{*}{0.045} & \multirow[t]{5}{*}{$\mathrm{S}$} \\
\hline & 1 & $10(28.6 \%)$ & $7(16.3 \%)$ & & & \\
\hline & 2 & $9(25.7 \%)$ & $15(34.9 \%)$ & & & \\
\hline & 3 & $6(17.1 \%)$ & $15(34.9 \%)$ & & & \\
\hline & 4 & $0(0.0 \%)$ & $2(4.7 \%)$ & & & \\
\hline
\end{tabular}

Table (3): Gender and coronary vessel plaques.

\begin{tabular}{|l|l|c|c|c|c|c|}
\hline \multicolumn{2}{|c|}{} & Female & Male & Test value & P-value & Sig. \\
\cline { 3 - 4 } \multicolumn{2}{|c|}{$\begin{array}{l}\text { No. of } \\
\text { vessels } \\
\text { affected }\end{array}$} & 0 & No. $\mathbf{2 9}$ & No. = 49 & & \\
\cline { 2 - 4 } & 1 & $8(27.6 \%)$ & $6(12.2 \%)$ & \multirow{2}{*}{$10.598^{*}$} & 0.031 & S \\
\cline { 2 - 4 } & 2 & $10(34.5 \%)$ & $7(14.3 \%)$ & & \\
\cline { 2 - 4 } & 3 & $7(24.1 \%)$ & $17(34.7 \%)$ & & \\
\cline { 2 - 4 } & 4 & $4(13.8 \%)$ & $17(34.7 \%)$ & & \\
\hline
\end{tabular}

Among patients with positive coronary plaques, $34(51.5 \%)$ were diabetic, while 32 (48.5\%) were not diabetic, P-value $<0.05$ : Significant. And $32 \quad(48.5 \%)$ were hypertensive (Diagram 3). Diabetic patients
The prevalence of coronary plaque increased with age Table 2. The prevalence of coronary plaque was significantly higher after age 55 years. The prevalence of coronary plaque increased in men, where multivessel affection was significantly higher (Table 3).

show a statistically significant higher incidence of multivessel affection than nondiabetic patients $(75 \%$ vs. $45 \%, \mathrm{P}$ value $<0.05)$.

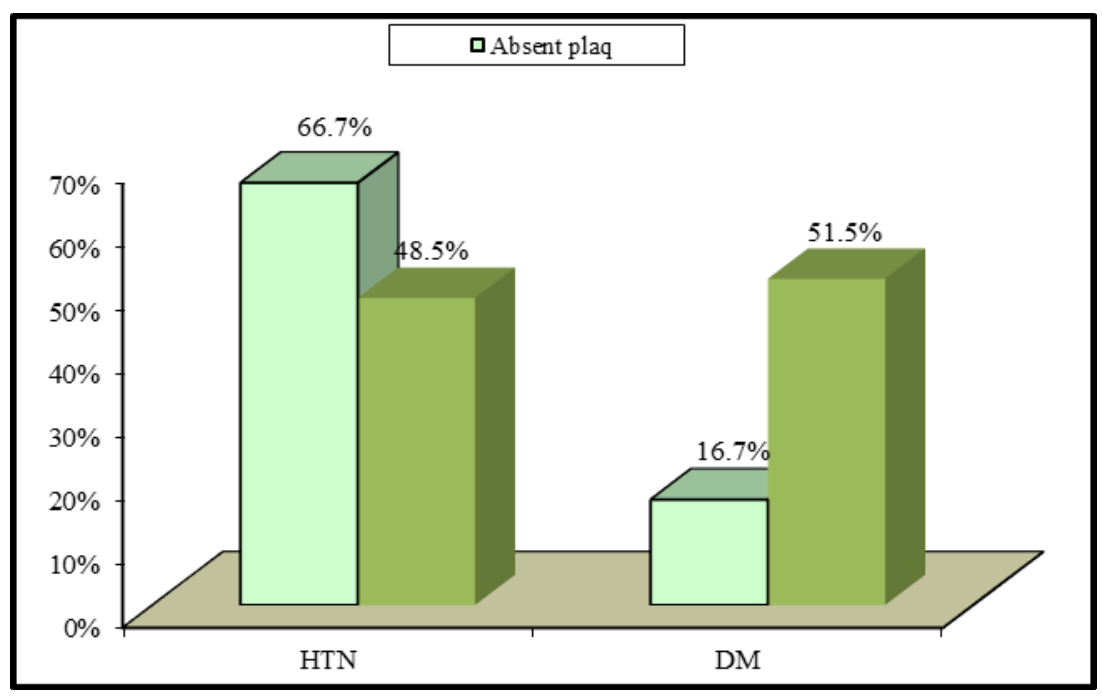

Diag. (3): Bar chart representation of patients with positive risk factors. 


\section{Coronary artery calcium (CAC)}

The distribution of patients according to different Agatston scores is shown in Table 4. Among 16 patients who had zero CAC Score, 6 patients $(37.5 \%)$ had CAD (with 15 non-calcified plaques, and mean plaque volume burden $=220)$, while $10(62.5 \%)$ had normal CTCA.

Patients $>55$ years old had a strong statistical significance of higher CAC than those $<55$ years (Median 58 in Patients $>55$ year Vs 4 in Patients $>55$ year, P-value $<0.05)$.
Table (4): distribution of patients according to different Agatston scores

\begin{tabular}{|l|l|}
\hline $\begin{array}{c}\text { AG } \\
\text { Score }\end{array}$ & No. $=\mathbf{7 8}$ \\
\hline 0 & $16(21 \%)$ \\
\hline $1-10$ & $18(23 \%)$ \\
\hline $11-$ & $25(32 \%)$ \\
100 & \\
\hline $101-$ & $16(82 \%)$ \\
400 & \\
\hline$>400$ & $3(3.80 \%)$ \\
\hline
\end{tabular}

\section{Type of plaques}

We found 232 lesions, among them, calcified plaques were the most common which represent $49.1 \%$, then non-calcified plaques were $41.3 \%$, while mixed plaques represented only $9.4 \%$. (Table $5,6 \& 7$ )

Table (5): Calcified plaques and their distribution among coronary vessels

\begin{tabular}{|c|c|c|}
\hline Calcified & \multicolumn{2}{|c|}{ No. $=114$} \\
\hline LAD & \multicolumn{2}{|c|}{$\sum \wedge(42.1 \%)$} \\
\hline LM & \multicolumn{2}{|c|}{$7(6.1 \%)$} \\
\hline LCX & \multicolumn{2}{|c|}{ r8 $(33.3 \%)$} \\
\hline $\mathrm{RCA}$ & \multicolumn{2}{|c|}{$r \backslash(18.4 \%)$} \\
\hline \multirow{2}{*}{ Total plaque Volume $1724 \mathrm{~mm}^{3}$} & Median (IQR) & $17.85(8-57)$ \\
\hline & $\begin{array}{l}\text { Range } \\
\text { Mean }\end{array}$ & $\begin{array}{c}4-111 \\
15\end{array}$ \\
\hline
\end{tabular}

Table (6): Non-Calcified plaques and their distribution among vessels

\begin{tabular}{|c|c|c|}
\hline Non-Calcified & \multicolumn{2}{|c|}{ No. $=96$} \\
\hline LAD & \multicolumn{2}{|c|}{$\varepsilon 6(47.9 \%)$} \\
\hline LM & \multicolumn{2}{|c|}{$4(4.1 \%)$} \\
\hline LCX & \multicolumn{2}{|c|}{$12(12.5 \%)$} \\
\hline RCA & \multicolumn{2}{|c|}{$34(35.4 \%)$} \\
\hline \multirow[t]{2}{*}{ Total plaque Volume 12670} & Median (IQR) & $180(80-326)$ \\
\hline & $\begin{array}{l}\text { Range } \\
\text { Mean }\end{array}$ & $\begin{array}{c}13-860 \\
132\end{array}$ \\
\hline
\end{tabular}

Table (7): Mixed plaques and their distribution among vessels

\begin{tabular}{|c|c|c|}
\hline Mixed & \multicolumn{2}{|c|}{ No. $=22$} \\
\hline LAD & \multicolumn{2}{|c|}{$1 \varepsilon(63.6 \%)$} \\
\hline LM & \multicolumn{2}{|c|}{$2(9 \%)$} \\
\hline LCX & \multicolumn{2}{|c|}{$2(9 \%)$} \\
\hline $\mathrm{RCA}$ & \multicolumn{2}{|c|}{$4(18 \%)$} \\
\hline \multirow{2}{*}{ Total plaque Volume 3108} & Median (IQR) & $147(34.5-255)$ \\
\hline & $\begin{array}{l}\text { Range } \\
\text { Mean }\end{array}$ & $\begin{array}{c}17-664 \\
141\end{array}$ \\
\hline
\end{tabular}




\section{Quantitative coronary plaque characterization with multidetector ct angiography}

Table (8): Plaque burden volumes of NCP and CCP by gender

\begin{tabular}{|c|c|c|c|c|c|c|}
\hline & Female & Male & \multirow{2}{*}{$\begin{array}{c}\text { Test } \\
\text { value }\end{array}$} & \multirow{2}{*}{$\begin{array}{c}\text { P- } \\
\text { value }\end{array}$} & \multirow[t]{2}{*}{ Sig } \\
\hline & & No. $=29$ & No. $=49$ & & & \\
\hline \multicolumn{7}{|l|}{ Calcified } \\
\hline \multirow{2}{*}{$\begin{array}{l}\text { Volume } \\
m m^{2}\end{array}$} & Median & $23(8-57)$ & $16(8-57)$ & \multirow[t]{2}{*}{$-0.293 \ddagger$} & \multirow[t]{2}{*}{0.769} & \multirow[t]{2}{*}{ NS } \\
\hline & Range & $7-66$ & $4-111$ & & & \\
\hline \multicolumn{7}{|c|}{ Non calcified } \\
\hline \multirow{2}{*}{$\begin{array}{l}\text { Volume } \\
m m^{s}\end{array}$} & $\begin{array}{l}\text { Median } \\
\text { (IOR) }\end{array}$ & $80(28-133)$ & $310(165-560)$ & \multirow[t]{2}{*}{$-3.939 \ddagger$} & \multirow[t]{2}{*}{0.000} & \multirow[t]{2}{*}{ HS } \\
\hline & Range & $13-154$ & $21-860$ & & & \\
\hline
\end{tabular}

A total of 312 coronary vessel, harboring 232 plaque. The most commonly affected vessel was the LAD artery $46.5 \%$, vs. $25.4 \%$ RCA , 22.4\% LCX and 5.6\% LM (Diagram 4).

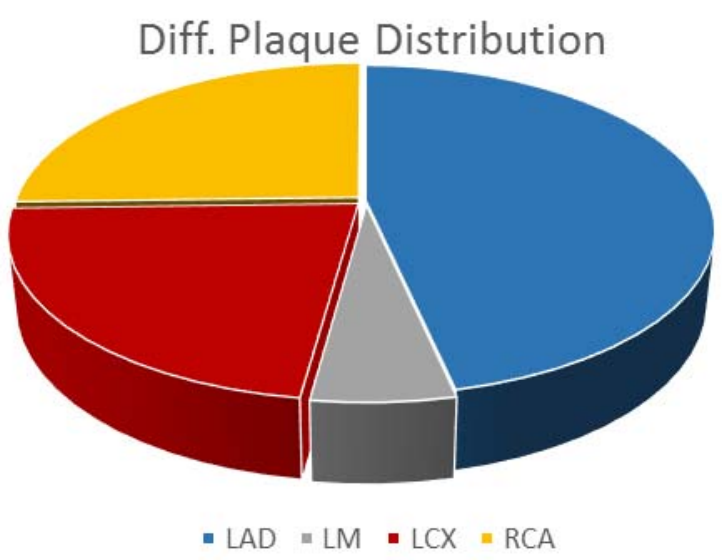

Diag. (4): Pie chart of percentage of coronary vessel affection

The plaque burden volumes of NCP and CCP by age and gender (Tables 8\&9). NCP volume was strongly associated with male gender.

Table (9): Plaque burden volumes of NCP and CCP by age

\begin{tabular}{|c|c|c|c|c|c|c|}
\hline & Age $<55$ & Age $>55$ & \multirow{2}{*}{$\begin{array}{c}\text { Test } \\
\text { value }\end{array}$} & \multirow{2}{*}{$\begin{array}{l}\mathrm{P}- \\
\text { value }\end{array}$} & \multirow[t]{2}{*}{ Sig } \\
\hline & & Patient No. $=35$ & Patient No. $=43$ & & & \\
\hline \multicolumn{7}{|c|}{ Calcified } \\
\hline \multirow{2}{*}{$\begin{array}{l}\text { Volume } \\
m m^{5}\end{array}$} & Median & $19.7(8-92)$ & $16(8-46)$ & \multirow[t]{2}{*}{-0.820} & \multirow{2}{*}{$\begin{array}{c}0.41 \\
2\end{array}$} & \multirow[t]{2}{*}{ NS } \\
\hline & Range & $5-95$ & $4-111$ & & & \\
\hline \multicolumn{7}{|c|}{ Non calcified } \\
\hline \multirow{2}{*}{$\begin{array}{l}\text { Volume } \\
m m^{3}\end{array}$} & Median & $184.5(90-560)$ & $180(67-326)$ & \multirow[t]{2}{*}{-0.516} & \multirow{2}{*}{$\begin{array}{c}0.60 \\
6\end{array}$} & \multirow[t]{2}{*}{ NS } \\
\hline & Range & $21-1000$ & $13-860$ & & & \\
\hline
\end{tabular}

Importantly, noncalcified plaques were more prevalent than calcified plaques, in those $<55$ years old, in whom $56.4 \%$ of their plaques were noncalcified, however, in patients $>55$ years old only $39.3 \%$ of their plaques were noncalcified. 


\section{DISCUSSION}

In the present study we found that the frequency of CAD among patients complaining from recent chest pain was $82.05 \%$. Among 78 patients we found $17.9 \%$ having normal CCTA, 47.4\% having significant CAD. In study conducted by Koulaouzidis et al.,2012 "CTCA as Initial Work-Up for Unstable Angina Pectoris" they found that among 43 patients 17 $(39.5 \%)$ had normal CTCA, and only 4 $(9.3 \%)$ had a significant obstructive lesion ${ }^{(9)}$.

In our study, Patients with two vessel disease were $30.8 \%, 26.9 \%$ had three vessel disease and $2.6 \%$ had three vessel and diseased LM.

Zero calcium score was detected in 16 case, however $37.5 \%$ of them show CAD. In 2011, Villines et al., noted in their study, that $16 \%$ of patients with zero CAC scores had CAD (13\% had nonobstructive stenosis, 3\% had $>50 \%$ stenosis). Patients with CAC scores of 0 have not yet developed detectable calcified coronary lesion, but they can have fatty streaking and early stages of plaque, non-calcified plaques up to obstructive disease. Noncalcified plaques are common in many young adults ${ }^{(10)}$.

In this present study, we found that patients $>55$ years old had a statistically significant higher CAC score than those < 55 years old (Median 58 Vs 4, P-value $<0.05$ ), while no statistically significant difference in CAC score between males and females.

We found that males show a statistically significant higher incidence of multivessel affection than females $(73 \%$ vs. $38 \%$, P value $<0.05)$. In 2010, Chu et al. ,stated that CT findings of CAD between men and women were nearly similar except that men had more calcified plaques $\left(\mathrm{p}<0.05^{)(11)}\right.$.

In our study, we found that diabetic patients show a statistically significant higher incidence of multivessel affection than nondiabetic patients $(75 \%$ vs. $45 \%$, $\mathrm{P}$ value $<0.05$ ). In 2010, Van Werkhoven et al., stated that diabetic patients showed a higher average number of diseased coronary segments (5.6 vs. $4.4, \mathrm{P}=.001$ ), weather obstructive or non-obstructive CAD ${ }^{(12)}$.

In our 78 patients, we found 232 coronary lesions, there were $9.5 \%$ mixed plaques, $49.1 \%$ calcific plaques, and $41.3 \%$ with soft plaques. The most common diseased coronary vessel was the LAD artery $46.5 \%$, vs. $25.4 \%$ RCA, $22.4 \%$ LCX and $5.6 \%$ LM. in 2015, Diaz-Zamudio et al, examined 56 coronary artery lesions, $64.3 \%$ were in the LAD, $26.8 \%$ were in the right coronary artery, and $8.9 \%$ were in the left circumflex coronary artery ${ }^{(13)}$.

Noncalcified plaques were more prevalent than calcified plaque in those $<55$ years old, in whom $56.4 \%$ of the plaques were noncalcified. In 2014, Kral et al., stated that in patients $<55$ years old, $75 \%$ of the plaques were noncalcified. It is noteworthy that coronary calcium may markedly underestimate the total plaque burden in this population $^{(14)}$.

Moreover, CAC score is not a useful marker for assessing the reduction of plaque after therapy, likely because CAC does not accurately reflect a change in modifiable noncalcified plaque.

The plaque burden volumes of NCP were significantly higher in males (median $310 \mathrm{~mm}^{3}$ Vs $80 \mathrm{~mm}^{3} \mathrm{n}$ females), with no significant difference in plaque volumes in different age groups.

The mean of plaque volumes in our study was $132 \mathrm{~mm}^{3}$ non-calcified plaques, and $15 \mathrm{~mm}^{3}$ calcified plaques. In 2011, Rinehart et al., calculated mean of plaque volumes was $223 \mathrm{~mm}^{3}$ non-calcified plaques, and $39 \mathrm{~mm}^{3}$ calcified plaques ${ }^{(15)}$.

The ability of CTCA to assess and characterize atherosclerotic plaque can help 


\section{Quantitative coronary plaque characterization with multidetector ct angiography}

\author{
interventional cardiologist in planning \\ percutaneous coronary intervention \\ strategies.
}

Using automated plaque quantification methods is supposed to reduce interobserver variability when compared to manual quantification techniques.

Limitations of this study include a relatively homogeneous population, as collected from a single site, with limited variation. Patients with severe renal failure were not eligible for coronary CT angiography. Measurement of plaque volume can be affected by technical factors such as tube voltage and contrast material injection rate.

\section{Conclusion}

Multi-slice CT coronary angiography is the non-invasive alternative to IVUS for plaque quantification, it is a reliable technique to detect $\mathrm{CAD}$ and estimate the degree of obstruction, number of affected vessels and the pattern of their affection. Using automated software provide the major advantage of highly reproducible assessments of lumen area, minimal lumen diameter, plaque burden, plaque volume and can be used in following the response to therapy.

\section{REFERENCES:}

1. Sun ZH, Rashmizal H, Xu L et al. (2014): Molecular imaging of plaques in coronary arteries with PET and SPECT. J Geriatr Cardiol ;11:259-73.

2. Baumann $\mathrm{S}$, Renker $\mathrm{M}$, Meinel $\mathrm{FG}$, et al(2015): Computed tomography imaging of coronary artery plaque: characterization and prognosis. Radiol Clin North Am. 2015;53(2):307-315.

Doi:10.1016/j.rcl.2014.11.008.

3. Sun Z.(2017): Quantitative assessment of coronary plaques by coronary CT angiography:High inter-reader and intrareader agreement is achieved but interscanner variability should not be ignored.
Heart Res Open J .2017;4

4. Leipsic J, Abbara S, Achenbach S et al (2014): SCCT guidelines for the interpretation and reporting of coronary CT angiography: A report of the Society of Cardiovascular Computed Tomography Guidelines Committee. Journal of Cardiovascular Computed Tomography, 8(5), 342-358.

5. Maurovich-horvat $\mathrm{P}$, Ferencik $\mathrm{M}$, Voros $\mathrm{S}$ et al (2014): Comprehensive plaque assessment by coronary CT angiography. Nat Publ Gr. 2014. Doi:10.1038/nrcardio.2014.60.

6. Pugliese F, Meijboom WB, Ligthart $\mathrm{J}$ et al (2009): Parameters for coronary plaque vulnerability assessed with multidetectorcomputed tomography and intracoronary ultrasound correlation . Journal of Cardiovascular Medicine2009, 10:821-826.

7. Opolski M.P. (2019): CT for Guiding Successful Revascularization. In: Schoepf U. (eds) CT of the Heart. Contemporary Medical Imaging. Humana, Totowa, NJ2019:pp 361-374.

8. Papadopoulou S L, Garcia-Garcia H M, Rossi A et al (2013): Reproducibility of computed tomography angiography data analysis using semiautomatic plaque quantification software: implications for the design of longitudinal studies. International Journal of Cardiovascular Imaging. 2013 Jun;29(5):1095-104.

9. Koulaouzidis, Powell, McArthur et al (2012): Computed tomography coronary angiography as initial work-up for unstable angina pectoris. Eur J Gen Med 2012;9(2):111-7.

10. Villines TC, Hulten EA, Shaw LJ, et al (2011): Prevalence and severity of coronary artery disease and adverse events among symptomatic patients with coronary artery calcification scores of zero undergoing coronary computed tomography angiography. J Am Coll Cardiol 2011;58(24):2533-40.

11. Chu ZG, Yang ZG, Dong ZH et al. (2010): Characteristics of coronary artery disease in 


\section{Ahmed Mostafa Mohamed, et al.,}

symptomatic type 2 diabetic patients: evaluation with CT angiography. CardiovascDiabetol 2010;9:74

12. Van Werkhoven JM, Cademartiri F, Seitun S, et al. (2010): Diabetes:prognostic value of CT coronary angiography comparison with a nondiabetic population. Radiology 2010;256(1):83-92

13. Diaz-Zamudio M, Dey D, Schuhbaeck A et al (2015): Angiography Noninvasively Predicts Hemodynamic Significance by Using Fractional Flow Reserve in Intermediate Coronary Lesions 1. 2015; 276 (2).

14. Kral BG, Becker LC, Vaidya D, et al
(2014): Noncalcified Coronary Plaque Volumes in Healthy People With a Family History of Early Onset Coronary Artery Disease. 2014:446-453. doi:10.1161/CIRCIMAGING.113.000980.

15. Rinehart S, Vazquez G, Qian Z et al (2011): Quantitative measurements of coronary arterial stenosis, plaque geometry, and composition are highly reproducible with a standardized coronary arterial computed tomographic approach in high-quality CT datasets. J Cardiovasc Comput Tomogr. 2011;5(1):35-43. doi:10.1016/j.jcct. 2010. 09.006.

\section{التوصيف الكمي للترسبات داخل الشرايين التاجية باستخدام الاشعة المقطعية متعددة المقاطع}

$$
\begin{aligned}
& \text { أحمد مصطفي محمد، أمير لويس لوقا ، علي حجاج علي ،شيماء صلاح محمد عبدالرازق. }
\end{aligned}
$$

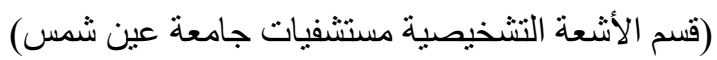

المقدمة: مرض الثريان التاجي هو سبب رئيسي للامر اض و الوفيات. تصلب الثرايين التاجي هو مرض لئن يمكن ان

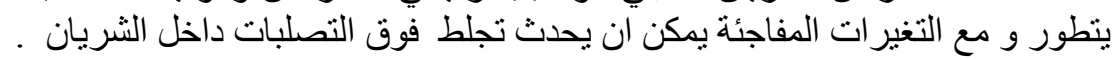

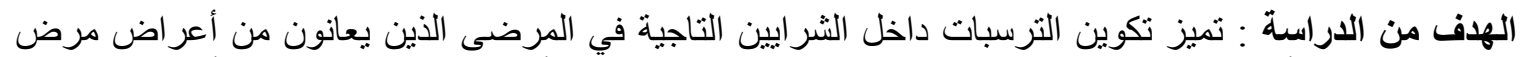

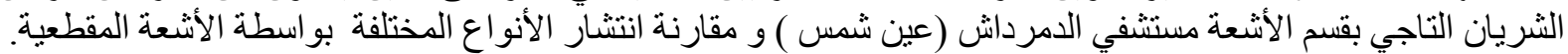

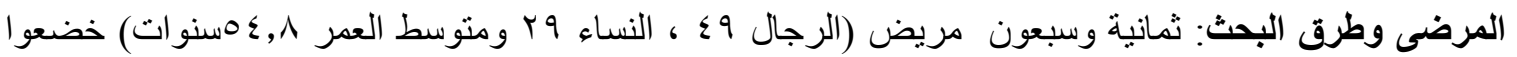

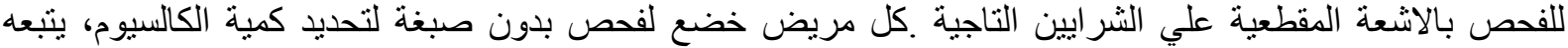
فحص بالصبغة ثم تحليل لاي لوحة تصلب من حيث العدد و النوع ونسبة ضيق الثريان و كمية الترسبات في الثرايين التاجية باستخدام بر امج التحليل.

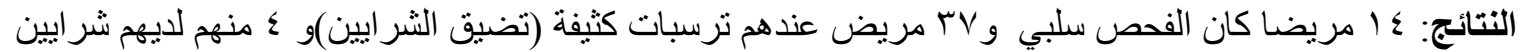

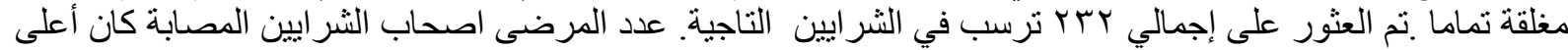

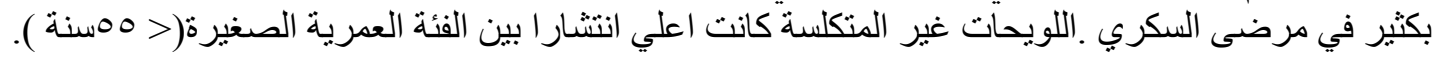
الخاتمة: الاشعة المقطعية متعددة المقاطع لتصوير الثرايين التاجية هي بديل القسطرة الغازية للتمييز الكمي

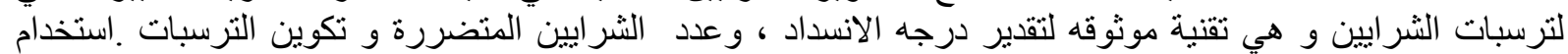

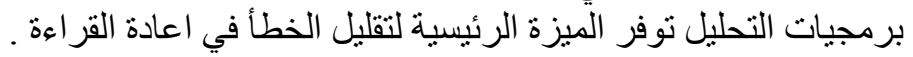

